\title{
Investment Reversibility and Agency Cost of Debt
}

\author{
Gustavo Manso*
}

October 24, 2007

\begin{abstract}
Previous research has argued that debt financing affects equityholders' investment decisions, producing substantial inefficiency. This paper shows that the size of this inefficiency depends on the degree of investment reversibility. In a dynamic model of financing and investment, the paper provides an upper bound for the inefficiency produced by debt financing. The upper bound is decreasing in the degree of investment reversibility and is zero when investment is perfectly reversible.
\end{abstract}

KEYWORDs: Agency problems, real options, debt financing, asset substitution, debt overhang, underinvestment.

*MIT Sloan School of Management, 50 Memorial Drive E52-446, Cambridge, MA 02142 (e-mail: manso@mit.edu). I thank Anat Admati, Malcolm Baker, Peter DeMarzo, Darrell Duffie, John Roberts, Ilya Strebulaev, a co-editor, and three anonymous referees for helpful comments. 


\section{Introduction}

The relation between financing and investment decisions of the firm has occupied the finance literature for the last fifty years. In their seminal work, Modigliani and Miller (1958) prove that if capital markets are perfect and investment decisions are fixed, then the value of the firm does not depend on its financing decisions. Subsequent work, however, has disputed the assumption that investment decisions can be taken independent of financing decisions. Jensen and Meckling (1976) argue that since equityholders do not bear the full cost of low returns, they have incentives to take riskier projects, potentially extracting value from the debtholders. This conflict of interest between the equityholders and the debtholders is referred to as the asset substitution problem. Myers (1977) argues that equityholders of a leveraged firm will underinvest because a fraction of the results of their investment will accrue to debtholders. This conflict of interest between the equityholders and debtholders is referred to as the debt overhang or underinvestment problem. The broad consensus at present is that the use of debt financing affects equityholders' investment decisions, producing substantial inefficiency, which is commonly referred to as agency cost of debt.

The contribution of this paper is to show that the agency cost of debt depends on the degree of investment reversibility. The analysis is based on the structural models of credit risk of Black and Cox (1976) and Leland (1994). However, instead of a fixed cash-flow process, it incorporates dynamic investment decisions as in Duffie (2001, pp. 271-272). In the model, the firm may switch over time among alternative technologies. Each technology has an associated cash-flow process that evolves exogenously according to a general 
diffusion process. When the firm switches from one technology to another it incurs a lump-sum switching cost. The result of the paper is that the agency cost of debt is lower than the present value of the maximum of the switching costs paid upon default. Therefore, if investment is perfectly reversible, in the sense that there are no switching costs between technologies, then debt financing does not lead to inefficient investment decisions.

The paper is related to the literature on real options, which studies dynamic investment decisions of the firm. Dixit and Pindyck (1994) provide a survey of the real options literature. A standard work in this literature that fits literally into the model of investment studied here is that of Dixit (1989), which analyzes entry and exit decisions of a firm whose output price follows a geometric Brownian motion. The optimal investment policy of an unlevered firm is characterized under the assumption that the firm pays a lump-sum cost every time it switches from active to inactive and vice-versa. Bentolila and Bertola (1990) and Abel and Eberly (1996) are other examples of real options models that study costly reversible investment. In contrast to the real options literature, I investigate investment distortions caused by debt financing.

More closely related to this paper is the literature on dynamic investment and financing decisions of the firm. ${ }^{1}$ For example, Mauer and Triantis (1994) study a firm that can costly shut-down and resume operations. Childs,

\footnotetext{
${ }^{1}$ This literature includes Mello and Parsons (1992), Mauer and Triantis (1994), Leland (1998), Mauer and Ott (2000), Décamps and Faure-Grimaud (2002), Hennessy (2004), Titman, Tompaidis, and Tsyplakov (2004), Childs, Mauer, and Ott (2005), Ju and OuYang (2006), Moyen (2007), Sundaresan and Wang (2006), and Lobanov and Strebulaev (2007).
} 
Mauer, and Ott (2005) study a firm that can costly exercise and reverse the exercise of a growth option. Other articles in this literature have assumptions that depart from the costly reversible investment framework and make the upper bound obtained here inapplicable. For example, Mauer and Ott (2000) study options to expand that cannot be reversed at any cost. Sundaresan and Wang (2006) study investment projects that must be taken in a given order. Lobanov and Strebulaev (2007) study growth options that are lost if not exercised at a particular time. Leland (1998) studies investment projects that, if taken, affect the future cash flows of the other available projects.

In addition to departures from the costly reversible investment framework, some articles in this literature consider alternative debt structures (finite-maturity debt and debt refinancing) and other market imperfections (bankruptcy costs and tax benefits of debt). The result obtained here can be extended to incorporate these alternative assumptions about debt structure and market imperfections, but for ease of exposition I restrict the analysis to financing through a consol bond with neither bankruptcy costs nor tax benefits of debt.

\section{The Model}

The model is based on Duffie (2001, pp. 271-272). The firm may switch over time among $m$ alternative technologies. The cash-flow rate processes $\delta \in \mathbb{R}^{m}$ of the $m$ available technologies follow a diffusion governed by the equation

$$
d \delta(t)=\mu(\delta(t), t) d t+\sigma(\delta(t), t) d B(t)
$$


where $\mu \in \mathbb{R}^{m}$ and $\sigma \in \mathbb{R}^{m} \times \mathbb{R}^{m}$ satisfy the classic assumptions for the existence of a unique strong solution to (1) and $B \in \mathbb{R}^{m}$ is a standard Brownian motion. If technology $i$ is employed at time $t$, it produces cash flows at the rate $\delta_{i}(t)$. When the firm switches from technology $i$ to technology $j$, it incurs a lump-sum cost $\varphi(i, j)$, with $\varphi(i, i)=0$.

A technology-choice process is a right-continuous adapted process $\zeta$ taking value in $\{1, \ldots, m\}$. At any time $t$ in which $\zeta(t) \neq \zeta(t-) \equiv \lim _{s \uparrow t} \zeta(s)$, the firm switches from technology $\zeta(t-)$ to $\zeta(t)$. The initial technology $\zeta_{0}$ is given. Given a technology-choice process $\zeta$, the firm's total cumulative cash flow by time $t$ is given by $D_{t}^{\zeta}$, where $D_{0}^{\zeta}=0$ and

$$
d D_{t}^{\zeta}=\delta_{\zeta(t)}(t) d t-\varphi(\zeta(t-), \zeta(t)) .
$$

All agents are risk-neutral and discount future cash flows at the rate $r$. The market value of the firm's total future cash flows at time $t$ is given by

$$
A_{t}^{\zeta}=E_{t}\left[\int_{t}^{\infty} e^{-r(s-t)} d D_{s}^{\zeta}\right]
$$

The market value of an all-equity firm at time $t$ is

$$
A_{t}^{\mathrm{fb}}=\sup _{\zeta} A_{t}^{\zeta} .
$$

The firm's capital structure consists of debt and equity. For simplicity, debt is in the form of a consol bond that promises to pay coupons at a total rate $c$, continually in time, until default. Equityholders receive the residual cash flow in the form of dividends at the rate $D_{t}^{\zeta}-c$ at time $t$, until default. At default, the firm's future cash flows are assigned to debtholders.

With debt at a coupon rate $c$, the valuation of equity at any time $t$ before 
default is

$$
S_{t}=\sup _{\zeta, T} E_{t}\left[\int_{t}^{T} e^{-r(s-t)} d D_{s}^{\zeta}-\int_{t}^{T} e^{-r(s-t)} c d s\right] .
$$

Given the technology-choice process $\zeta^{*}$ and the default stopping time $T^{*}$ of equityholders, the valuation of debt at any time $t$ before default is

$$
Y_{t}=E_{t}\left[\int_{t}^{T^{*}} e^{-r(s-t)} c d s+e^{-r\left(T^{*}-t\right)} A_{T^{*}}^{\zeta^{*}}\right] .
$$

Because of the conflict of interest between equityholders and debtholders, one expects inefficiencies due to investment distortions to arise. Equityholders may engage in asset substitution, choosing risky and inefficient technologies, or underinvestment, staying longer with inefficient technologies to avoid paying the switching costs.

The agency cost of debt is defined as

$$
\alpha_{t}=A_{t}^{\mathrm{fb}}-\left(S_{t}+Y_{t}\right) .
$$

It is equal to the difference between the total value of the all-equity and levered firms. Since there are no other market imperfections in the model, the agency cost of debt captures the loss in value of the firm due to the investment distortions produced by the presence of debt.

Proposition 1 provides an upper bound for the agency cost of debt.

Proposition 1 The agency costs $\alpha_{t}$ of debt are bounded above by

$$
E_{t}\left[e^{-r\left(T^{*}-t\right)} \max _{i, j} \varphi(i, j)\right]
$$


Proof Adding equations (3) and (4), we have

$$
\begin{aligned}
S_{t}+Y_{t}=E_{t}\left[\int_{t}^{T^{*}} e^{-r(s-t)} d D_{s}^{\zeta^{*}}-\int_{t}^{T^{*}} e^{-r(s-t)} c\right] \\
+E_{t}\left[\int_{t}^{T^{*}} e^{-r(s-t)} c\right]+E_{t}\left[e^{-r\left(T^{*}-t\right)} A_{T^{*}}^{\zeta^{*}}\right] .
\end{aligned}
$$

where $\zeta^{*}$ and $T^{*}$ are the solutions to (3). The value of the unlevered firm can be written as

$$
\begin{aligned}
A_{t}^{\mathrm{fb}}=E_{t}\left[\int_{t}^{T^{*}} e^{-r(s-t)} d D_{s}^{\zeta^{\mathrm{fb}}}\right. & \left.-\int_{t}^{T^{*}} e^{-r(s-t)} c\right] \\
& +E_{t}\left[\int_{t}^{T^{*}} e^{-r(s-t)} c\right]+E_{t}\left[e^{-r\left(T^{*}-t\right)} A_{T^{*}}^{\mathrm{fb}^{*}}\right] .
\end{aligned}
$$

where the first-best policy $\zeta^{\mathrm{fb}}$ is the solution to the investment problem (2) of an all-equity firm.

Because equityholders maximize the present value of cash flows minus coupon payments before default,

$$
\begin{aligned}
& E_{t}\left[\int_{t}^{T^{*}} e^{-r(s-t)} d D_{s}^{\zeta^{*}}-\int_{t}^{T^{*}} e^{-r(s-t)} c\right] \geq \\
& E_{t}\left[\int_{t}^{T^{*}} e^{-r(s-t)} d D_{s}^{\zeta^{\mathrm{fb}}}-\int_{t}^{T^{*}} e^{-r(s-t)} c\right]
\end{aligned}
$$

After default, the debtholders take control of the firm and can switch to any technology by paying a switching cost. Therefore,

$$
E_{t}\left[e^{-r\left(T^{*}-t\right)} A_{T^{*}}^{\zeta^{\mathrm{fb}}}\right]-E_{t}\left[e^{-r\left(T^{*}-t\right)} A_{T^{*}}^{\zeta^{*}}\right] \leq E_{t}\left[e^{-r\left(T^{*}-t\right)} \max _{i, j} \varphi(i, j)\right] .
$$

The upper bound on $\alpha_{t}$ follows from (6), (7), (8), and (9).

The upper bound (5) is the present value of the maximum of the switching costs paid upon default. The intuition for the result is as follows. Equityholders maximize the present value of cash flows minus coupon payments before 
default. Therefore, the present value of cash flows before default must be greater than or equal to what it would have been under the first-best policy. It is thus only after default that investment distortions due to the presence of debt can negatively impact the firm's cash flows. After default, debtholders take control of the firm and maximize the present value of cash flows of the firm. However, by paying a switching cost, debtholders can obtain from that point on exactly the same cash flows as if the first-best investment policy had been used all the way until default. Therefore, the agency cost of debt must be lower than the present value of the maximum of the switching costs paid upon default.

\section{References}

Abel, A., and J. Eberly, 1996, Optimal Investment with Costly Reversibility, Review of Economic Studies 63, 581-593.

Bentolila, S., and G. Bertola, 1990, Firing Costs and Labour Demand: How Bad is Eurosclerosis, Review of Economic Studies 57, 381-402.

Black, F., and J. Cox, 1976, Valuing Corporate Securities: Some Effects of Bond Identures Provisions, Journal of Finance 31, 351-367.

Childs, P., D. Mauer, and S. Ott, 2005, Interactions of Corporate Financing and Investment Decisions: The Effects of Agency Conflicts, Journal of Financial Economics 76, 667-690.

Décamps, J., and A. Faure-Grimaud, 2002, Excessive Continuation and Dynamic Agency Cost of Debt, European Economic Review 46, 1623-1644. 
Dixit, A., 1989, Entry and Exit Decisions Under Uncertainty, Journal of Political Economy 97, 620-638.

Dixit, A., and R. Pindyck, 1994, Investment Under Uncertainty. (Princeton University Press Princeton).

Duffie, D., 2001, Dynamic Asset Pricing Theory. (Princeton University Press New Jersey) third edn.

Hennessy, C., 2004, Tobin's Q, Debt Overhang, and Investment, Journal of Finance 59, 1717-1742.

Jensen, M., and W. Meckling, 1976, Theory of the Firm: Managerial Behavior, Agency Costs, and Ownership Structure, Journal of Financial Economics 3, 305-360.

Ju, N., and H. Ou-Yang, 2006, Asset Substitution and Underinvestment: A Dynamic View, Working paper, Duke University.

Leland, H., 1994, Corporate Debt Value, Bond Covenants, and Optimal Capital Structure, Journal of Finance 49, 1213-1252.

Leland, H., 1998, Agency Costs, Risk Management, and Capital Structure, Journal of Finance 53, 1213-1243.

Lobanov, S., and I. Strebulaev, 2007, A Theory of Dynamic Financing and Investment, Working paper, Stanford GSB.

Mauer, D., and S. Ott, 2000, Agency Costs, Underinvestment, and Optimal Capital Structure: The Effect of Growth Options to Expand, in M. Bren- 
nan, and L. Trigeorgis, eds.: Project Flexibility, Agency, and Competition (Oxford University Press, Oxford ).

Mauer, D., and A. Triantis, 1994, Interactions fo Corporate Financing and Investment Decisions: A Dynamic Framework, Journal of Finance 49, $1253-1277$.

Mello, A., and J. Parsons, 1992, Measuring the Agency Cost of Debt, Journal of Finance 47, 1887-1904.

Modigliani, F., and M. Miller, 1958, The Cost of Capital, Corporation Finance and the Theory of Investment, American Economic Review 48, $267-$ 297.

Moyen, N., 2007, How Big is the Debt Overhang Problem?, Journal of Economic Dynamics and Control 31, 433-472.

Myers, S., 1977, Determinants of Corporate Borrowings, Journal of Financial Economics 5, 147-175.

Sundaresan, S., and N. Wang, 2006, Dynamic Investment, Capital Structure, and Debt Overhang, Working paper, Columbia University.

Titman, S., S. Tompaidis, and S. Tsyplakov, 2004, Market Imperfections, Investment Flexibility, and Default Spreads, Journal of Finance 59, 165205. 